\title{
New data on middle and late Albian foraminifera and biostratigraphy of the northern palaeobiogeographical district of western Siberia
}

\author{
Vera M. Podobina \\ Tomsk State University, 36 Lenin Avenue, Tomsk, Russia \\ e-mail: podobina@ggf.tsu.ru
}

\begin{abstract}
The present paper discusses foraminiferal assemblages and biozones established on the basis of studies of samples from ten borehole sequences of the Khanty-Mansiysk Horizon in the Samotlor area of the northern palaeobiogeographical district of western Siberia (Russia). In this region, middle and late Albian foraminiferal assemblages were first distinguished in western Siberia. Levels from which these assemblages have been recovered, are here referred to the following foraminiferal zones, the Ammobaculites fragmentarius-Gaudryinopsis filiformis Zone (middle Albian) and the Ammotium braunsteini-Verneuilinoides borealis assanoviensis Zone (upper Albian). Zonal assemblages are dominated by representatives of the orders Ammodiscida, Textulariida and Ataxophragmiida. Species of the ataxophragmiid genera Verneuilinoides, Pseudoverneuilina and Gaudryinopsis are the most characteristic, inclusive of several key index forms. Foraminiferal tests consist of agglutinated quartz-silica, the wall microstructure being almost exclusively medium and coarse grained. In specific composition, the Albian assemblages from the Samotlor area are similar to those from Transuralia (Russia) and to the Canadian Province, which, together with West-Siberian Province, forms the Arctic palaeobiogeographical realm.
\end{abstract}

Keywords: foraminifera, biostratigraphy, Albian, West-Siberian Province

\section{Introduction}

Albian strata across most of western Siberia comprise the continental facies of the Khanty-Mansiysk Horizon (Pokurskaya Series). In the Samotlor area, however, this horizon is marine in nature, encompassing various lithologies such as grey sandstones, siltstones and dark-grey claystones.

Previously, marine Albian strata of Transuralia (i.e., the territory along the eastern slope of the Ural Mountains), with foraminifera and macrofossil taxa were studied and described by a number of authors.

Bulatova (1976) studied Albian foraminifera and biostratigraphy in detail and, on their basis, established a number of microfaunal zones and subzones. Problems of the Albian Stage in western Siberia were comprehensively dealt with by Zakharov et al. (2000); its occurrence was documented by finds of ammonites, inoceramid bivalves and partially supported by data on foraminifera. Amon (2005) summarized lithological data of the Khanty-Mansiysk Horizon and described Albian foraminiferal assemblages then known from Transuralia. Moreover, he provided information on both macrofaunal remains and microfauna as recorded previously by a number of authors.

The present paper discusses results of the author's studies of rich foraminiferal assemblages of middle and late Albian age in the Samotlor area. As far as tectonic features are concerned, this area represents a structural high which is confined to the central part of the Nizhnevartovsk area, lo- 
cated slightly northwards of the Ob river middle reaches (Fig. 1).

The West-Siberian Province was subdivided by Podobina (1995) into a number of palaeobiogeographical districts. Transuralia is restricted to the western district, while the central portion of western Siberia, situated north of the Ob river middle reaches, has been defined as the northern district. It is to this district that the Samotlor area belongs. For the present note, comparisons have been made (see Section 3 below) between Albian assemblages from the Samotlor area and those from Transuralia, as previously published in papers on Albian biostratigraphy (Bulatova, 1976; Zakharov et al., 2000; Amon, 2005). A close generic and specific similarity has been noted, thus enabling a revision of the Albian biozones of western Siberia.

\section{Material and methods}

Ninety-three core samples, from ten localities (boreholes 1, 2, 4, 168, 177, 650, 734, 19975, 21119 and 38027) in the Samotlor area, have been analysed for
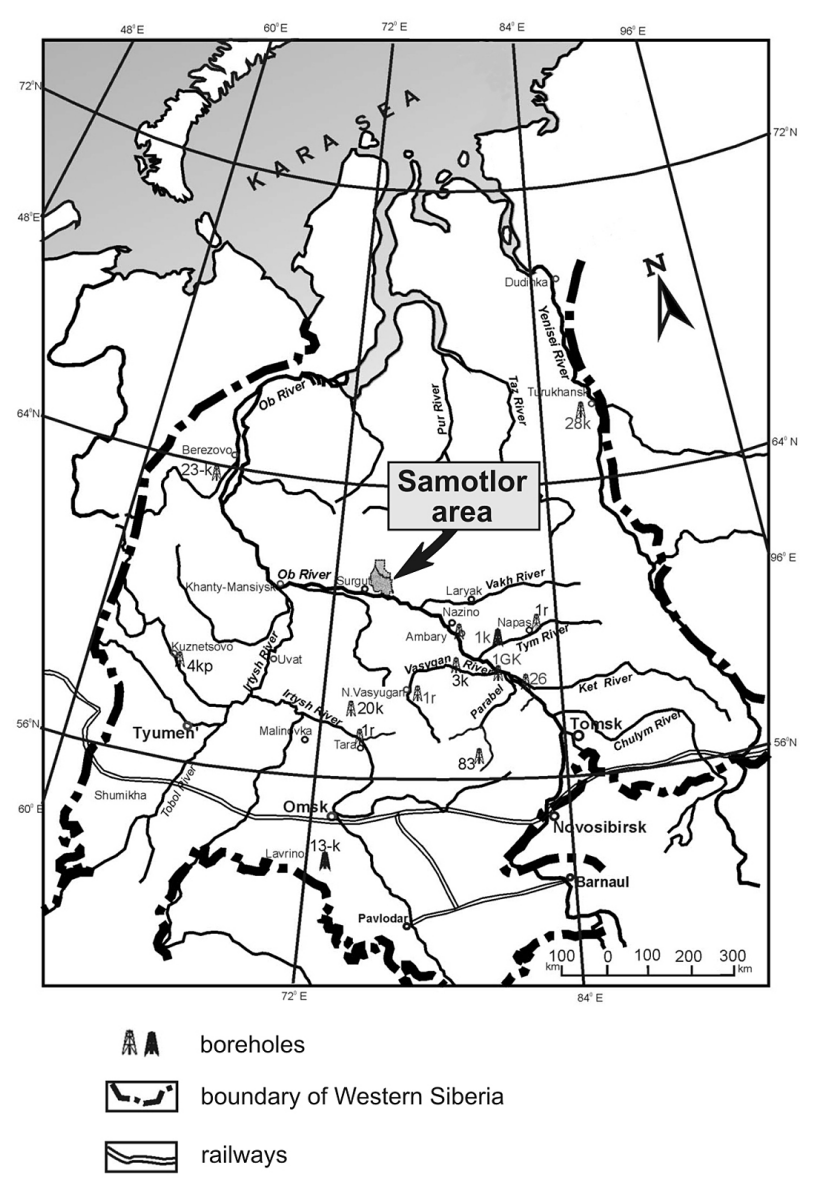

Fig. 1. Location of borehole sections in western Siberia studied herein. microfaunal content. Almost the entire territory of the Khanty-Mansiysk Horizon (Pokurskaya Series; see Figs. 1, 2) has been investigated for the presence of foraminifera in these samples.

All samples yielded agglutinated quartz-siliceous foraminifera with a coarse-grained wall microstructure. In some samples, pseudomorphs of calcareous foraminifera were encountered, but the taxonomic status was assessed only in a part of them. Taxonomic diversity and test preservation were consistent in samples studied. The best test preservation and highest abundance were found in about 87 samples, which thus enabled an extensive investigation of their systematic composition and distribution amongst sections exposing this horizon. A full systematic treatment of all assemblages, with exact indication of index species, is deferred to another occasion. My views on Albian assemblages and their distribution to a certain degree match results obtained by Bulatova (1976) for Transuralia.

My study of foraminifera from these ten borehole sequences documents a predominance of members of the following orders: Ammodiscida, Ataxophragmiida and Textulariida. The pseudomorphs of former calcareous forms with the higher rate of integrity are assigned to the order Rotaliida. In generic assignments, I have for many years used the established national classification of foraminifera (Rauser-Chernousova \& Furssenko, 1959), and have discussed this on several occasions (Podobina, 1978,

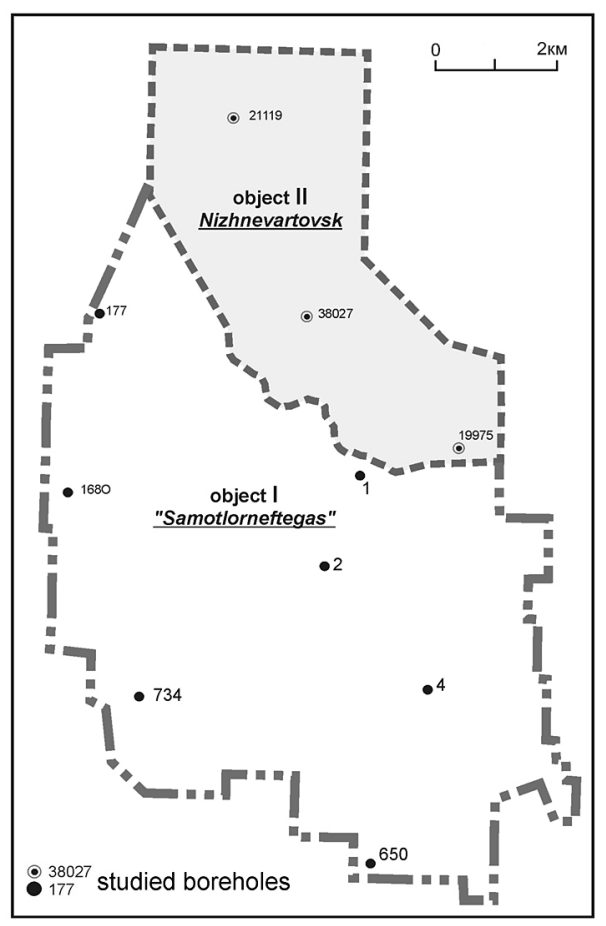

Fig. 2. Location of borehole sections studied in the Samotlor area. 
1993, 2014), duly considering the chemical composition and morphological peculiarities of their tests.

Here, I wish to indicate my reasons for not applying more recent foraminiferal classificatory schemes, including that by Kaminski (2004) which placed all agglutinated foraminifera in the subclass Textulariia Mikhalevich, 1980. This subclass comprises numerous orders, suborders, superfamilies, families, subfamilies and genera. In my opinion, based on chemical wall composition (mainly agglutination), agglutinated foraminifera can be subdivided into carbonaceous and siliceous forms (Podobina, 1978, 1993). Thus, on this evidence, Podobina (1978) preferred two superfamilies, the Haplophragmiidea and Lituolidea, rather than one (Lituolidea; order Lituolida sensu Kaminski, 2004). As opposed to the Haplophragmiidea (type species: Haplophragmoides canariensis Cushman), in lituolideans (type species: Lituola nautiloidea Lamark), the test wall is calcareous and the morphological structure more complex (Podobina, 1978). In view of the fact that chemical composition and morphological test features have mostly not been taken into account, the classification proposed by M. Kaminski is not applied here.

For a long time now, starting in the 1970s (Podobina, 1978) and continuing to the present day (Podobina, 2014), I have been elaborating the classification of the class Foraminifera d'Orbigny, 1826, which encompasses 15 subclasses, and different numbers of orders.

In the Samotlor area, two sets of wells (so-called objects) are distinguished: Object I "Samotlorneftegas" (English "Samotlor oil and gas") with boreholes 1, 2, 4, 168, 177, 650 and 734, and Object II "Nizhnevartovsk" with boreholes 19975, 21119 and 38027 (Fig. 2).

A preliminary study of foraminifera from borehole 650 (Object I) has demonstrated the presence of middle and upper Albian of the Khanty-Mansiysk Horizon, comparable to the other sequences grouped in this object. These deposits yield mainly numerous agglutinated quartz-siliceous foraminifera of diverse systematic composition. In some samples, a few yellowish pseudomorphs of calcareous forms were encountered. Agglutinated foraminifera of the order Haplophragmiida (Podobina, 2014) are predominated by representatives of two families: Haplophragmoididae and Haplophragmiidae, and of the orders Ataxophragmiida (genera Verneuilinoides, Gaudryinopsis and Pseudoverneuilina) and Textulariida (Spiroplectammina). The abundance of ataxophragmiids provides evidence of some deepening of the Boreal basin, especially during the middle Albian.
Along with ataxophragmiids, species of Ammotium (Haplophragmiidae) and of Spiroplectammina (Textulariida), are typical of the upper Albian deposits. The presence of pseudomorphs of calcareous foraminifera in some samples (borehole 650) suggests that some warming occurred in the shallow basin during this time interval.

Middle-late Albian foraminiferal assemblages have also been recognized in borehole 734 , to the north. They are similar in systematic composition and overall aspect to those from borehole 650, implying comparable palaeoecological conditions in the southern part of the Boreal basin.

A larger sample set is known from borehole 4, situated slightly north of borehole 650; 20 samples in total. These have allowed the middle-upper Albian deposits to be characterized in more detail as far as foraminiferal assemblages are concerned. The middle Albian shows a predominance of members of Gaudryinopsis and Pseudoverneuilina, and of the families Haplophragmoididae (genera Labrospira, Haplophragmoides, Recurvoides) and Haplophragmiidae (Ammobaculites). In samples taken from lesser depths in borehole 4, numbers of tests of Verneuilinoides and Ammotium increased, as did those of other members of the orders Astrorhizida, Ammodiscida, Ataxophragmiida and Textulariida.

In summary, study of core samples and identification of foraminiferal assemblages in all ten boreholes sections in the Samotlor area, have resulted in the recognition of the middle and upper Albian substages and the corresponding foraminiferal zones. The following table (Table 1) presents the depth ranges from where foraminifera were recov-

Table 1. Distribution of foraminifera within Albian strata in the Samotlor area.

\begin{tabular}{ccc}
\hline Stage Zone & $\begin{array}{c}\text { Upper Albian } \\
\text { Ammotium braun- } \\
\text { steini-Verneui- } \\
\text { linoides borealis } \\
\text { assanoviensis }\end{array}$ & $\begin{array}{c}\text { Middle Albian } \\
\text { Ammobaculites } \\
\text { fragmentarius - } \\
\text { Gaudryinopsis } \\
\text { filiformis }\end{array}$ \\
\hline borehole number & depth range [m] & depth range [m] \\
\hline 650 & $1725.3-1741.4$ & 1742.7 \\
\hline 734 & $1740.5-1758.9$ & $1758.9-1764.9$ \\
4 & $1658.3-1684.55$ & $1701.13-1738.5$ \\
\hline 1 & $1669.1-1731.36$ & $1724.8-1731.36$ \\
\hline 2 & $1662.0-1668.0$ & $1740.8-1747.3$ \\
\hline 168 & $1668.0-1740.8$ & $1763.8-1794.8$ \\
\hline 177 & - & $1769.5-1776.8$ \\
19975 & $1744.0-1769.5$ & $1834.0-1838.0$ \\
\hline 38027 & $1726.0-1834.0$ & $1746.6-1788.0$ \\
\hline 21119 & - & $1810.4-1831.4$ \\
\hline
\end{tabular}


ered, and at which the Ammotium braunsteini-Verneuilinoides borealis assanoviensis and Ammobaculites fragmentarius-Gaudryinopsis filiformis zones were established.

In an earlier study of core samples from the Samotlor area (Podobina, 2013), I erected a new genus, Pseudoverneuilina, and three new species, Spiroplectammina cognata Podobina (Pl. II, Fig. 3; Pl. IV, Fig. 1), S. sibirica Podobina (Pl. III, Fig. 3; Pl. IV, Fig. 2), and Pseudoverneuilina albica Podobina (Pl. III, Fig. 4).

\section{Comparison between the Samotlor area and Transularia (Arctic palaeobiogeographical realm)}

A comparison of Albian foraminiferal assemblages from the Samotlor area with those from Transuralia has demonstrated some similarities in generic and specific composition. Tests of almost all Samotlor foraminifera, in contrast to those from Transuralia, are poorly preserved and are mediumand coarse-grained. However, some common species can be differentiated from those of Transuralia, northern Alaska and northern Canada, and this permits two Albian foraminiferal assemblages with index species to be established for the Samotlor sequences. The middle Albian assemblage has two index species: Ammobaculites fragmentarius Cushman (Pl. I, Fig. 4) and Gaudryinopsis filiformis (Berthelin) (Pl. III, Fig. 2), while the upper Albian is characterised by Ammotium braunsteini (Cushman \& Applin) (Pl. II, figs. 1, 2) and Verneuilinoides borealis Tappan assanoviensis (Zaspelova) (Pl. II, Fig. 5; Pl. IV, Fig. 3) (see Podobina, 2013). Lower Albian strata have not yet been recorded. In the most recent Regional Stratigraphic Chart (2005) of the Albian of western Siberia (Transuralia), V. borealis Tappan assanoviensis (Zaspelova) is held to be typical of the entire Albian Stage, but is also shown as an index species for the middle and upper Albian, together with various species of Ammosiphonia (i.e., A. jamaica for the upper Albian; A. beresoviensis for the middle Albian). However, I am of the opinion that these two species must be assigned to the Genus Ammotium Loeblich \& Tappan.

Based on all morphological features, including chemical test composition (quartz-siliceous) and the coarse-grained wall structure, Ammotium is here considered typical of Albian strata of the western Siberian and Canadian provinces (Tappan, 1962). Ammosiphonia He, 1977 is known from older rocks (Triassic) in China, and is more often distributed in southern provinces (Loeblich \& Tappan, 1987/1988). Verneuilinoides borealis assanoviensis occurs mainly in the upper layers of the Khanty-Mansiysk Horizon, and may be considered as the index species for the upper Albian zone. I concur with Bulatova (1976), who characterized the upper Albian on the basis of this taxon. The other index species, Ammotium braunsteini (Cushman \& Applin) (Pl. II, Figs. 1, 2), also remains characteristic ones of the upper Albian.

I believe that the assignment of lower, middle and upper Albian strata, to a single zone, the Verneuilinoides borealis assanoniensis Zone (as ratified in the last Regional Stratigraphic Chart, 2005), is inexpedient. It is preferable to use distinct foraminiferal zones for each substage, as previously demonstrated by Bulatova (1976) for Transuralia and by myself (Podobina, 2013) for the Samotlor area in western Siberia.

Numerous quartz-siliceous foraminifera have been recovered from all studied boreholes in that area. On their basis, the Albian is divided into two zones, i.e., the middle Albian Ammobaculites fragmentarius-Gaudryinopsis filiformis Zone and the upper Albian Ammotium braunsteini-Verneuilinoides borealis assanoviensis Zone.

Middle Albian levels have been penetrated in five boreholes of Object I, comprising an alternation of grey sandstones and siltstones. (Table 1; Fig. 2). Large numbers of tests of the following species are known from the middle Albian: Recurvoides leushiensis Bulatova (P1. I, Fig. 2), Ammobaculites fragmentarius Cushman and Gaudryinopsis filiformis (Berthelin). In borehole 177 (depth range 1769.5-1776.8 m), the same species have been found to predominate, along with peculiar, short pyramidal tests of Pseudoverneuilina albica Podobina (Pl. III, Fig. 4). Pseudomorphs of calcareous forms were encountered as isolated specimens in nearly all middle Albian sequences. As noted by Podobina (2013), the following species are typical of the Ammobaculites fragmentarius-Gaudryinopsis filiformis Zone: Hyperammina pulverea Bulatova, Reophax troyeri Tappan, Haplophragmoides reconditus Bulatova, Recurvoides leushiensis Bulatova, Ammobaculites fragmentarius Cushman, Ammomarginulina cragini Loeblich \& Tappan, Spiroplectammina cognata Podobina (Pl. II, Fig. 3; Pl. IV, Fig. 4), Gaudryinopsis filiformis (Berthelin), G. cf. oblongus (Zaspelova) and Pseudoverneuilina albica Podobina.

Numbers of specimens encountered of these species are not equal. Commonest are tests of the genera Haplophragmoides, Recurvoides, Ammobaculites, Pseudoverneuilina and Gaudryinopsis. The state of preservation also varies, but complete tests document 
the principal systematic composition of the middle Albian Ammobaculites fragmentarius-Gaudryinopsis filiformis Zone.

It is worth noting that in middle Albian deposits, isolated specimens of $V$. borealis Tappan assanoviensis (Zaspelova) are also found, but at this stratigraphic level, they are not the prime tools in dating this zone. Most typical of the middle Albian are, in addition to the index species, Recurvoides leushiensis Bulatova and Pseudoverneuilina albica Podobina. The latter genus bears some similarities to Verneuilina d'Orbigny, 1840, but is distinguished in having a quartz-siliceous test wall (rather than calcareous),

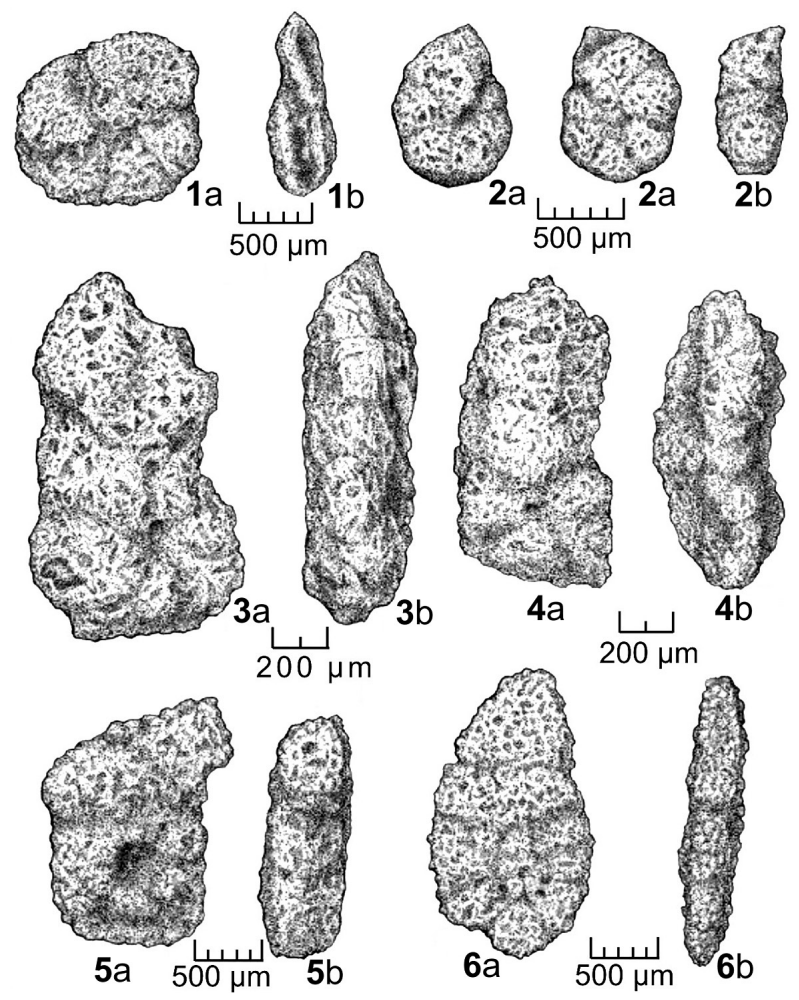

Plate I. Middle-late Albian foraminifera from the Khanty-Mansiysk Horizon (Samotlor area, western Siberia); a - lateral view; b - apertural view. All specimens are stored in the Palaeontological Museum of Tomsk State University (TSU) and in the Laboratory of Micropalaeontology of the TSU Siberian Palaeontological Centre.

Fig. 1. Haplophragmoides topagorukensis Tappan, specimen no. 3015; borehole 4, depth $1673.6 \mathrm{~m}$, upper Albian; Fig. 2. Recurvoides leushiensis Bulatova, specimen no. 3016; borehole 4, depth 1670.8 m, upper Albian; Fig. 3. Ammobaculites wenonahae Tappan, specimen no. 3017; borehole 4, depth 1670.8 m, upper Albian; Fig. 4. Ammobaculites fragmentarius Cushman, specimen no. 3018; borehole 21119, depth $1818.8 \mathrm{~m}$, middle Albian; Figs. 5, 6. Ammomarginulina obscura (Loeblich), specimens nos. 3019 and 3020, respectively; borehole 4, depth $1670.8 \mathrm{~m}$ and $1675.9 \mathrm{~m}$, respectively, upper Albian. and a rapidly expanding, low test (i.e., an upturned pyramid), triangular in section (Pl. III, Fig. 4).

Middle Albian deposits in Object II were penetrated in all three boreholes, 19975 (south), 21119 and 38027 (both north). In borehole 19975 (depth range $1826.0-1838.0 \mathrm{~m}$ ), grey pseudomorphs of poorly preserved agglutinated tests are predominant at depths $1834.97 \mathrm{~m}$ and $1836.98 \mathrm{~m}$; at depth $1837.8 \mathrm{~m}$, pseudomorphs of calcareous forms of the order Rotaliida are mainly encountered. Similar middle Albian foraminifera are known from the northern section of borehole 21119 (depth range 1810.4-1831.4 m). Here, the middle Albian Ammobaculites fragmentarius-
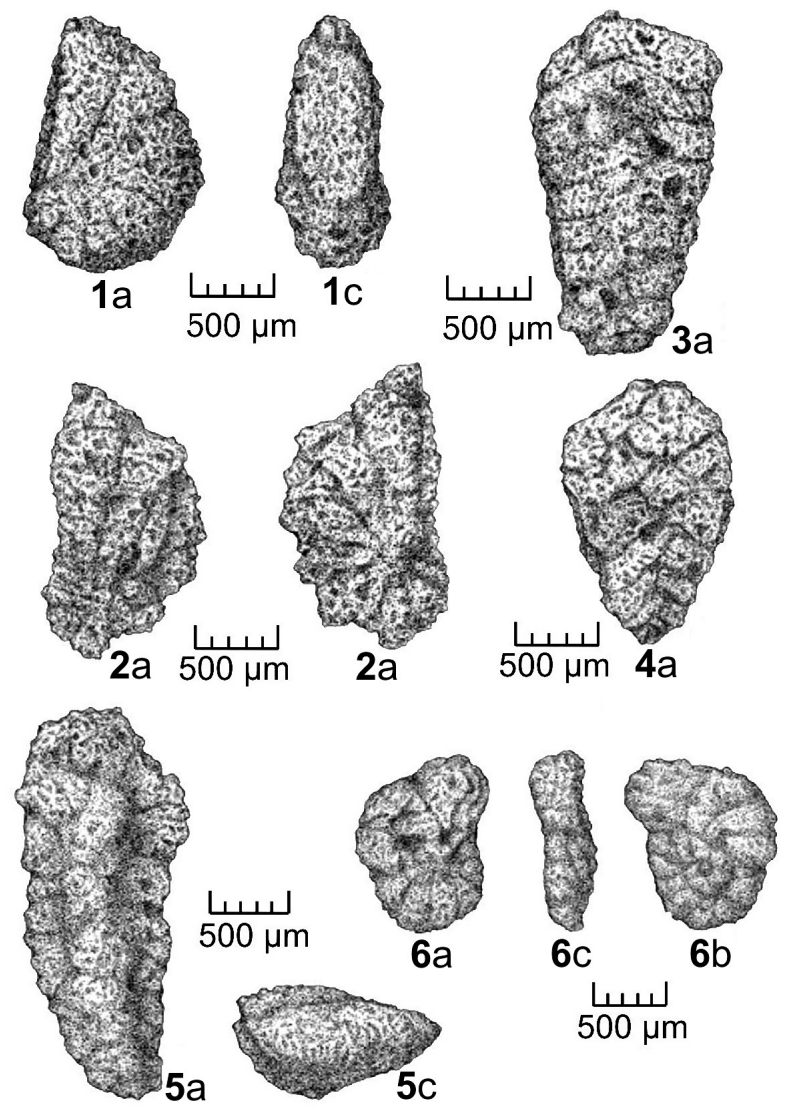

Plate II. Late Albian Foraminifera from the Khanty-Mansiysk Horizon (Samotlor area, western Siberia); a lateral or dorsal view; $\mathrm{b}$ - ventral view; $\mathrm{c}$ - apertural view.

Figs. 1, 2. Ammotium braunsteini (Cushman \& Applin), specimen no. 3300; borehole 650, depth $1734.1 \mathrm{~m}$; specimen no. 3301: borehole 734, depth $1741.5 \mathrm{~m}$, respectively; Fig. 3. Spiroplectammina cognata Podobina, holotype, no. 3302; borehole 650, depth 1740.5 m; Fig. 4. Flabellammina acuminata Podobina, specimen no. 3304; borehole 650, depth 1741.4 m; Fig. 5. Verneuilinoides borealis Tappan assanoviensis (Zaspelova), specimen no. 3305; borehole 650, depth 1730.5 m; Fig. 6 . Trochammina reinwateri Cushman \& Applin, specimen no. 3306; borehole 650, depth $1730.5 \mathrm{~m}$. 
Gaudryinopsis filiformis Assemblage has been documented for the lower half of the Khanty-Mansiysk Horizon of the Samotlor area (Table 1; Pls I-IV).

Upper Albian deposits, composed of alternating grey and dark-grey siltstones, occur in seven sequences within Object I and in two sections of Object II (Fig. 2). From borehole 650 (depth range 1725.3-1741.4 m), late Albian foraminifera of the Ammotium braunsteini-Verneuilinoides borealis assanoviensis have been recovered. In borehole 734 (depth range 1740.5-1758.9 m), a similar agglutinated quartz-siliceous foraminiferal association occurs, encompassing mainly Labrospira, Haplophragmoides, Ammomarginulina, Ammotium, Ammobaculites and

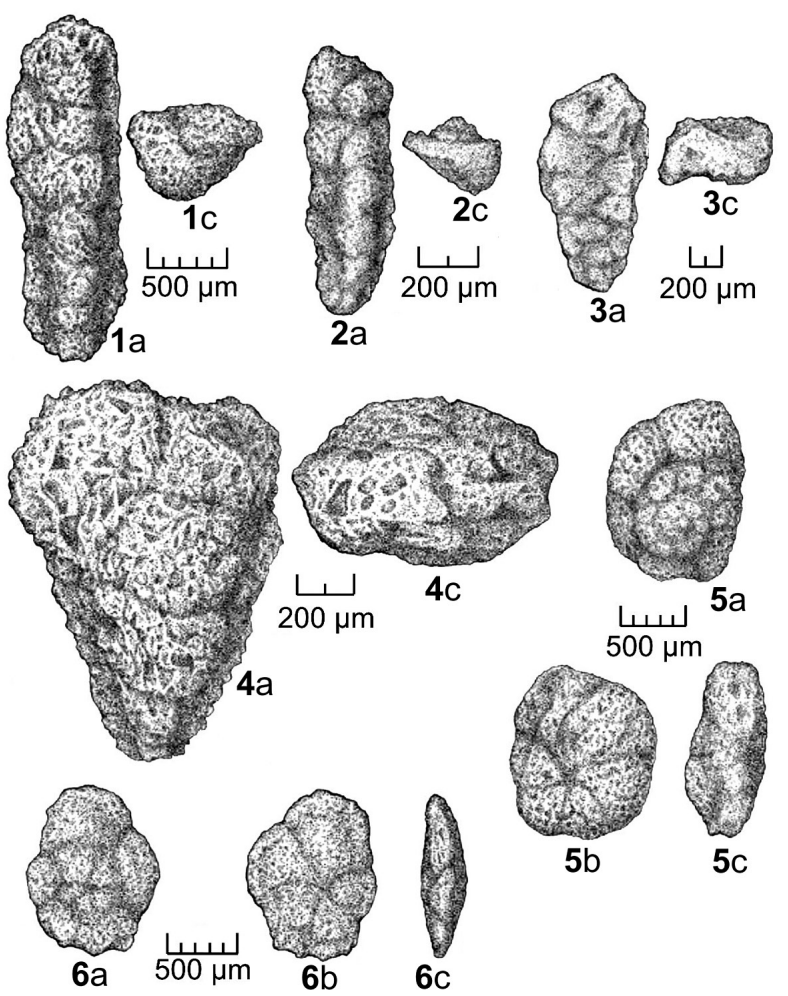

Plate III. Middle-late Albian Foraminifera from the Khanty-Mansiysk Horizon (Samotlor area, western Siberia); a - lateral or dorsal view; b - ventral view; c - apertural view.

Fig. 1. Gaudryinopsis improvisus (Bulatova), specimen no. 3307; borehole 19975, depth $1833.1 \mathrm{~m}$, middle Albian; Fig. 2. Gaudryinopsis filiformis (Berthelin), specimen no. 3308; borehole 19975, depth 1835.7 m, middle Albian; Fig. 3. Spiroplectinata sibirica Podobina, specimen no. 3309; borehole 1, depth 1691.1 m, upper Albian; Fig. 4. Pseudoverneuilina albica Podobina, specimen no. 3310; borehole 21119, depth 1819.2 m, middle Albian; Fig. 5. Trochammina reinwateri Cushman \& Applin, specimen no. 3311; borehole 4, depth $1673.6 \mathrm{~m}$, upper Albian; Fig. 6. Trochammina imiatensis Tappan, specimen no. 3312; borehole 743, depth $1750.8 \mathrm{~m}$, upper Albian.
Gaudryinopsis. In this section, the late Albian Ammotium braunsteini-Verneuilinoides borealis assanoviensis Assemblage is easily distinguished (Table 1).

In borehole 4 (depth range 1658.0-1684.55 m), located just north of borehole 650, the late Albian assemblage, with the same index species, has also been demonstrated. The assemblage is quite diverse systematically, being composed of Labrospira angustolocularia (Bulatova), Haplophragmoides cushmani Loeblich \& Tappan, H. reconditus Bulatova, Ammobaculites subcretaceus Cushman \& Alexander, Ammomarginulina obscura (Loeblich), Ammotium braunsteini (Cushman \& Applin), Pseudobolivina rayi (Tappan), Spiroplectammina sibirica Podobina,

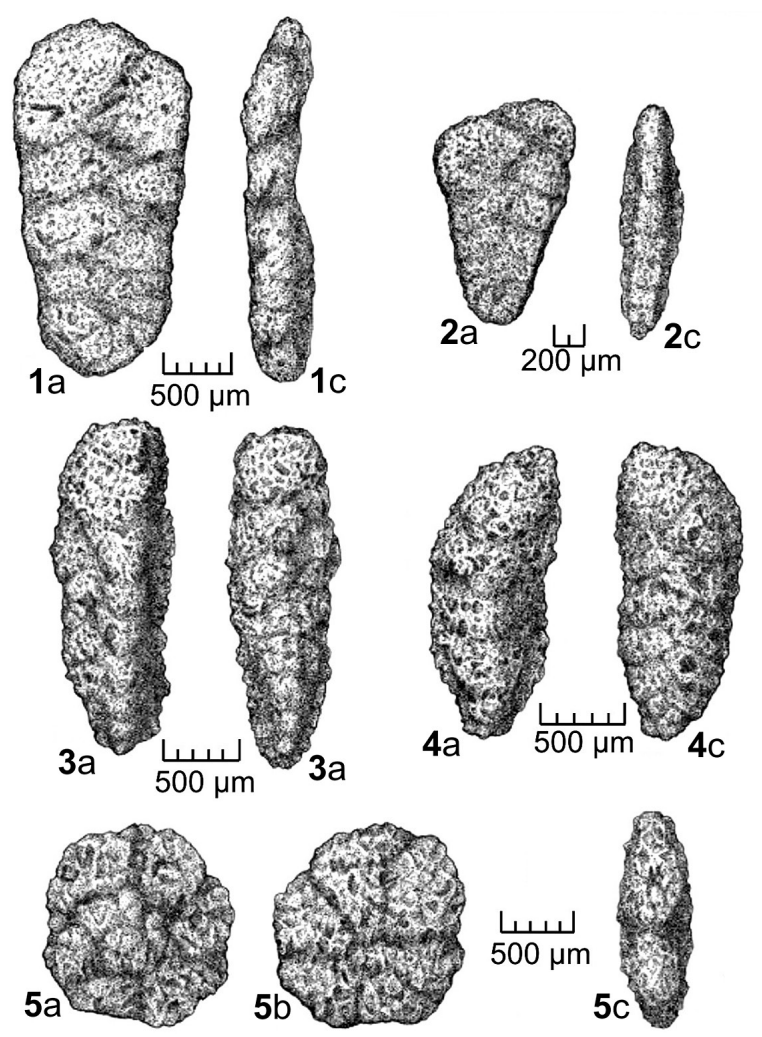

Plate IV. Middle-late Foraminifera from the Khanty-Mansiysk Horizon (Samotlor area, western Siberia); a - lateral or dorsal view; b - ventral view; c apertural view.

Fig. 1. Spiroplectammina cognata Podobina, specimen no. 3022; borehole 4, depth 1738.3 m, middle Albian; Fig. 2. Spiroplectammina sibirica Podobina, holotype, no. 3023; borehole 4, depth 1673.6 m, upper Albian; Fig. 3. Verneuilinoides borealis Tappan assanoviensis (Zaspelova), specimen no. 3024; borehole 4, depth 1676.8 m, upper Albian; Fig. 4. Gaudryinopsis improvisus (Bulatova), specimen no. 3025; borehole 4, depth 1673.6 $\mathrm{m}$, upper Albian; Fig. 5. Trochammina reinwateri Cushman \& Applin, specimen no. 3026; borehole 4, depth $1670.8 \mathrm{~m}$, upper Albian. 
Verneuilinoides borealis Tappan assanoviensis (Zaspelova) and Gaudryinopsis oblongus (Zaspelova). Commonest are representatives of Haplophragmoides, Ammomarginulina, Ammotium, Verneuilinoides and Gaudryinopsis. The coarse-grained fractions of sieved core samples almost entirely consist of medium- and coarse-grained foraminiferal tests.

In borehole 1 (depth range 1669.1-1731.36 m) and borehole 2 (depth range 1662.0-1740.8 m), grouped in Object I, late Albian species of the Ammotium braunsteini-Verneuilinoides borealis assanoviensis Assemblage are encountered. The systematic specific composition of this assemblage and that of associations from boreholes 650, 734 and 4 are similar. Upper Albian samples from these boreholes are dominated by representatives of Haplophragmoides, Ammomarginulina, Ammotium, Verneuilinoides and Gaudryinopsis. Test preservation and systematic composition are similar to boreholes 4, 650 and 734 .

In borehole 177 (depth range 1744.0-1769.5 m), late Albian foraminifera were also recognized, forming the Ammotium braunsteini-Verneuilinoides borealis assanoviensis Assemblage, yielding nearly the same species composition as in all other sections of Object I studied.

As to Object II, in borehole 19975 (depth range 1826.0-1834.0 m) and borehole 38027 (depth range 1720.0-1746.6 m), upper Albian deposits are distributed. They contain the assemblage Ammotium braunsteini-Verneuilinoides borealis assanoviensis of a similar systematic composition as in those from boreholes 650 and 734 . In all samples, the microstructure of test walls is medium and coarse grained. Test preservation varies, but for the most part, they are poorly preserved. However, a species composition characteristic of the upper Albian has been ascertained for these sections, despite the poorly preserved, deformed nature of many tests.

\section{Conclusions}

The present paper summarizes results of studies of marine deposits of the Khanty-Mansiisk Horizon (Pokurskaya Series) in western Siberia.

For the first time in western Siberia, common middle and late Albian assemblages of agglutinated foraminifera have been distinguished in ten borehole sections of the Samotlor area.

Based on species composition, two assemblages have been established, viz. the middle Albian Ammobaculites fragmentarius-Gaudryinopsis filiformis Zone and the upper Albian Ammotium braunsteiniVerneuilinoides borealis assanoviensis Zone. The lower
Albian has not yet been discovered by foraminifera in the Samotlor area.

Some of the species in these two Albian assemblages were found both in Samotlor area and in the Canadian Province (northern Canada, Wall, 1967; northern Alaska, Tappan, 1962), which, together with the West-Siberian Province, is assigned to the Arctic palaeobiogeographic Realm.

The species of two Albian assemblages are presented on four plates. Three foraminiferal species, viz. Spiroplectammina cognata Podobina, S. sibirica Podobina, Pseudoverneuilina albica Podobina and one genus Pseudoverneuilina have been distinguished by me and are described in the previous publication (Podobina, 2013).

\section{Acknowledgements}

I appreciate the kindness and assistance of all colleagues at the Laboratory of Micropaleontology (Tomsk State University), who participated in the technical preparation of the samples, investigation and processing of this manuscript. I would also like to thank two anonymous reviewers for their valuable critical comments on the manuscript.

\section{References}

Amon, E.O., 2005. Agglutinated foraminifera assemblages from Khanty-Mansiysk suite (Albian, lower Cretaceous) in the middle and south Zauralye (Trans-Urals). Lithosphere 2, 197-134 [in Russian]

Bulatova, Z.I., 1976. Stratigraphy of the Aptian-Albian oiland-gas bearing deposits of the West-Siberian plain by foraminifera. Nedra, Moscow, 152 pp. [in Russian]

Kaminski, M.A., 2004. The Year 2000 classification of agglutinated foraminifera. In: M. Bubik and M.A. Kaminski (eds.). Proceedings of the sixth international workshop on agglutinated foraminifera. Grzybowski Foundation Special Publication 8, pp. 237-255.

Loeblich, A. \& Tappan, H., 1953. Studies of Arctic Foraminifera. Smithsonian Miscellaneous Collection 121 (7), $150 \mathrm{p}$.

Loeblich, A.R. \& Tappan, H., 1987/1988. Foraminiferal genera and their classification. V.I, 970 p.; V.II, 847 pls., Van Nostrand Reinhold Comp., New York.

Podobina, V.M., 1978. Taxonomy and phylogeny of Haplophragmiidea. Publishing House of Tomsk State University, Tomsk, 91 p. [in Russian].

Podobina, V.M., 1993. New data on composition and microstructure of agglutinated foraminifer wall. [In:] Abstracts to International Conference on Agglutinated Foraminifers, 15, Cracow.

Podobina, V.M., 1995. Paleozoogeographic regionalization of Northern Hemisphere Late Cretaceous basin 
based on foraminifera. [In:] Kaminski, M.A., Geroch, S. \& Gasinski, M.A. (Eds), Proceedings of the $4^{\text {th }}$ International Workshop on Agglutinated Foraminifera. Grzybowski Foundation Special Publication, Cracow, 3, 239-247.

Podobina, V.M., 2013. Biostratigraphy of the Albian of the Samotlor area of Western Siberia (based on foraminifera). Vestnik TSU 374, 188-198 [in Russian]

Podobina, V.M., 2014. The suggested system of foraminifera (higher taxa). Tomsk State University Bulletin 380, 215-224 [in Russian]

Rauzer-Chernousova, D.M. \& Fursenko, A.V. (Eds), 1959. General part. Protozoans. vol. 1. [In:] Orlov, Yu.A. (Ed.), Fundamentals of Palaeontology. The manual for paleontologists and geologists of the USSR. Publishing House of the USSR Academy of Sciences, Moscow, 367 p., 13 pls. [in Russian]

Tappan, H, 1962. Foraminifera from the Arctic slope of Alaska, part 3. Cretaceous Foraminifera. Professional Papers U.S. Geological Survey 236 C, 91-209.
The Regional Stratigraphic Chart of the Cretaceous deposits of Western Siberia (Aptian - Albian - Cenomanian), 2005. $6^{\text {th }}$ Interdepartmental Stratigraphic Meeting. Stratigraphic Committee of Russian Federation, Novosibirsk [in Russian]

Wall, J. H., 1967. Cretaceous foraminifera of the Rocky Mountain foothills, Alberta. Research Council of Alberta Bulletin 20, 195 pp., 15 pls.

Zakharov, V. A., Marinov, V. A. \& Agalakov, S. E., 2000. The Albian Stage in Western Siberia. Geology and Geophysics 41, 769-791 [in Russian]

Manuscript submitted 6 December 2013 Revision accepted 15 January 2015 